\title{
Increased vitamin $D$ is associated with decline of naïve, but accumulation of effector, CD8 T cells during early aging
}

\author{
Yong Gil Hwang ${ }^{1}$, Hui-Chen Hsu ${ }^{1}$, Fei Chu Lim ${ }^{1}$, Qi Wu ${ }^{1}$, PingAr Yang ${ }^{1}$, Gordon Fisher ${ }^{2}$, \\ Gary R. Hunter ${ }^{2}$, John D. Mountz ${ }^{1,3^{*}}$ \\ ${ }^{1}$ University of Alabama at Birmingham, Division of Clinical Immunology and Rheumatology, Birmingham, AL, USA \\ ${ }^{2}$ Department of Human Studies, University of Alabama at Birmingham, Birmingham, AL, USA \\ ${ }^{3}$ Birmingham VA Medical Center, Birmingham, AL, USA; ${ }^{*}$ Corresponding Author: jdmountz@uab.edu
}

Received 13 March 2013; revised 13 April 2013; accepted 20 April 2013

Copyright (C) 2013 Yong Gil Hwang et al. This is an open access article distributed under the Creative Commons Attribution License, which permits unrestricted use, distribution, and reproduction in any medium, provided the original work is properly cited.

\begin{abstract}
Given the protective roles of 25-hydroxyvitamin D (25(OH)D or vitamin D) in musculoskeletal heaIth and the potential beneficial effects of vitamin $D$ supplementation in reducing the risk of various chronic diseases, intensive repletion of vitamin $D$ has been widely advocated. Of note, CD8 T cells have the highest levels of the vitamin $D$ receptor compared with other major immune cells. The effects of vitamin D on CD8 T cells during aging, however, remain unclear. This study determined the relationship between vitamin D levels and CD8 $T$ cell status in 34 healthy female subjects (all $>60$ years old). The CD8 T-cell phenotype was defined by the surface expression of CD28 and CD95. The low-25(OH)D serum groups $(\leq 30 \mathrm{ng} / \mathrm{ml})$ had higher percentages of $\mathrm{CD}^{+} 8^{+} \mathrm{CD} 95^{-} \mathrm{CD8}^{+}$(naïve) $\mathrm{T}$ cells and lower percentages of $\mathrm{CD}^{+} 8^{+} \mathrm{CD} 95^{+} \mathrm{CD} 8^{+}$(effector) $T$ cells. By contrast, subjects with high levels of 25(OH)D had very low percentages of naïve CD8 $T$ cells but very high percentages of effector CD8 $T$ cells. There was a significant inverse correlation between 25(OH)D levels and the frequency of naïve CD8 T cells. The results show that higher levels of vitamin $D$ are correlated with decreased frequencies of naïve CD8 $T$ cells during early aging, suggesting that higher levels of 25(OH)D accelerate CD8 $T$ cell senescence. These results warrant further evaluation of the effects of vitamin $D$ supplementation in immune aging.
\end{abstract}

Keywords: Naïve CD8; Immunosenescence;

\section{Vitamin D; Human}

\section{INTRODUCTION}

Aging is accompanied by immunologic and endocrinologic changes. The former are associated with both a gradual loss of naïve $\mathrm{T}$ cells and an accumulation of memory or senescent $T$ cells $[1,2]$. Senescent CD8 T cells, which have high levels of killer Ig-like receptor (KIR) and short telomeres, are associated with increased prevalence of carotid artery lesions and adverse health outcomes $[3,4]$. In addition, a substantial proportion of the elderly population have suboptimal 25-hydroxyvitamin $\mathrm{D}(25(\mathrm{OH}) \mathrm{D})$ concentrations from the perspective of bone heath and possibly other chronic diseases, including cancer, cardiovascular disease, diabetes, autoimmune disease, and Alzheimer's disease [5-13]. A potentially beneficial role of vitamin D supplementation in reducing the risk of various chronic diseases has been widely accepted based on observational studies, but to our knowledge, there has been no large, long-term, randomized trial. Furthermore, the optimal serum concentration of $25(\mathrm{OH}) \mathrm{D}$ is still controversial, and possible effects of high levels of $25(\mathrm{OH}) \mathrm{D}$ on the aging process remain a possibility. The majority of in vitro and epidemiologic studies suggest that the optimal serum concentration of $25(\mathrm{OH}) \mathrm{D}$ is $30 \mathrm{ng} / \mathrm{ml}$ or greater for maintaining bone mineral density (BMD), lower-extremity function, and dental health and minimizing the risk of falls and fractures [14-16]. However, the underlying rationale for setting the lower limit of the normal range at 30 $\mathrm{ng} / \mathrm{ml}$ is being questioned, given substantial individual variation in the PTH response to $25(\mathrm{OH}) \mathrm{D}$ and insufficient data to establish absolute cutoff levels of $25(\mathrm{OH}) \mathrm{D}$ for maximal calcium absorption [17-19]. Recent studies 
have shown a U-shaped association between $25(\mathrm{OH}) \mathrm{D}$ concentrations and adverse outcomes [17] and those associated with oral administration of high-dose cholecalciferol [20]. In addition, experimental studies have shown that not only low but also high $25(\mathrm{OH}) \mathrm{D}$ concentrations can accelerate aging and be deleterious to health [21,22].

The effects of vitamin D are mediated through its interaction with a high-affinity nuclear vitamin $\mathrm{D}$ receptor (VDR), a member of the nuclear receptor superfamily of ligand-activated transcription factors [23,24]. Brain, prostate, breast, and colon tissues, among others, as well as immune cells express a VDR. Interestingly, among immune cells (CD4, CD8, B cells, and macrophages), it was noted that $\mathrm{CD} 8 \mathrm{~T}$ cells express the highest concentrations of VDR [25]. Naïve T cells do not express VDR, but it was induced by $\mathrm{T}$ cell receptor (TCR) signaling via the alternative mitogen-activated protein kinase p38 pathway. This initial TCR signaling via $\mathrm{p} 38$ leads to successive induction of VDR and phospholipase C- $\gamma 1$ (PLC- $\gamma 1$ ), which are required for subsequent classical TCR signaling and $\mathrm{T}$ cell activation. Thus, vitamin D exhibits a unique function in enhancing TCR signaling [26]. By contrast, in autoimmune mice, administration of vitamin D prevented development of autoimmune encephalomyelitis (EAE), suggesting that in chronically stimulated $\mathrm{T}$ cells, vitamin $\mathrm{D}$ acts as a suppressor rather than an activator [27].

Our understanding of the effects of vitamin D on CD8 $\mathrm{T}$ cells during aging remains limited. Given the reported adverse health outcomes associated with $\mathrm{T}$ cell sensecence $[3,4]$ and high vitamin D concentration [28,29], we investigated the relationship between serum $25(\mathrm{OH})$ $\mathrm{D}$ concentration and CD8 T cell populations in healthy young elderly women.

Our previous studies have identified specific biomarkers for naïve $\left(\mathrm{CD} 28^{+} \mathrm{CD} 95^{-}\right)$, effector $\left(\mathrm{CD} 28^{+} \mathrm{CD} 95^{+}\right)$ and senescent $\left(\mathrm{CD} 28^{-} \mathrm{CD} 95^{+}\right) \mathrm{CD} 8 \mathrm{~T}$ cells [30]. Briefly, we verified these phenotypes by measuring the relative number of $\mathrm{T}$ cell receptor recombination excision circles (TRECs), which decline with cellular proliferation and with thymic involution. In addition, we assessed the expression of CD45RA, which is an established marker of resting naïve $\mathrm{T}$ cells, and $\mathrm{CD} 45 \mathrm{RO}$, which is a marker of activation commonly found on memory and effector cells for each phenotype [31]. We also analyzed the expression of CD127 (the IL-7R alpha chain), which is expressed on all mature $\mathrm{CD} 8^{+} \mathrm{T}$ cells after emigration from the thymus. Dow-nregulation of CD127 is associated primarily with $\mathrm{T}$ cell activation, whereas memory cells express high levels of CD127 [32]. From these data, we showed that $\mathrm{CD} 28^{+} \mathrm{CD} 95^{-} \mathrm{CD} 8^{+} \mathrm{T}$ cells are primarily composed of naïve $\mathrm{CD} 8^{+} \mathrm{T}$ cells, that the $\mathrm{CD} 28^{+} \mathrm{CD} 95^{+}$ $\mathrm{CD}^{+} \mathrm{T}$ cells are largely composed of memory cells, and that the $\mathrm{CD} 28^{-} \mathrm{CD} 95^{+} \mathrm{CD} 8^{+} \mathrm{T}$ cells are predominantly composed of terminally differentiated effector memory CD8 T cells [30]. Using these markers, we found in this study that the frequency of naïve CD8 T cells in peripheral blood mononuclear cells (PBMC) exhibited a significant negative correlation with circulating levels of 25(OH)D.

\section{MATERIALS AND METHODS}

\subsection{Subjects}

A subset of 34 healthy participants from an ongoing clinical trial known as "Frequency of Aerobic/Resistance Training in Older Women" (Clinical Trials.gov, identifier NCTOl 031394) were studied. Healthy Caucasian or African-American women over 60 years of age were eligible for this study. Subjects that were excluded from the study included all those with diabetes, unstable cardiovascular disease, or mental health problems requiring pharmacologic intervention. Also excluded were those subjects who had sustained a cardiovascular or cerebrovascular accident in the three months prior to evaluation, had severe high blood pressure, had evidence of aneurysm, were taking certain medications used for myasthenia gravis, or had uncontrolled asthma, an asthmalike condition, or emphysema/chronic obstructive pulmonary disease (COPD). All subjects who had been diagnosed with cancer, were undergoing immunotherapy or receiving immune suppressants, showed symptoms of allergy or a recent history of infection, and had been vaccinated with pneumovax, influenza, or other types of vaccine within the last 3 years were also excluded to minimize the heterogeneity of immune responses elicited in vaccinated versus non-vaccinated individuals. Those who smoked, had osteoporosis, or were unable to perform weight-bearing exercises were also excluded. The studies were approved by the institutional review board at the University of Alabama at Birmingham, and informed consent was obtained.

\subsection{Purification and Preparation of Peripheral Blood Mononuclear Cells (PBMCs)}

PBMCs were isolated from 34 healthy female subjects, age greater than 60 . As we described in the earlier study [30], heparinized peripheral blood was collected and spun to isolate the buffy coat layer, which was then centrifuged through a Histopaque gradient (Sigma-Aldrich, St. Louis, MO) for $30 \mathrm{~min}$ at $1700 \mathrm{rpm}$, and the PBMCs collected from the interface.

\subsection{Measurements}

Serum $25(\mathrm{OH}) \mathrm{D}$ levels were determined by using the 25(OH)D ELISA Kit (intra-assay coefficient of variation, $3.34 \%$, Inter Medico). Serum levels of inflammatory 
cytokines IFN- $\gamma$, IL-1, IL-6, and IL-17 and the Th2 cytokine IL-4 were determined by ELISA. Blood pressure, lipid profile, and body composition data were measured. Body fat and bone density were determined by dual-energy X-ray absorptiometry.

\subsection{Cell Phenotypes}

Cell phenotypes were examined by standard flow cytometry procedures as previously described [30]. This involved six-color immunofluorescence staining of cell samples using a combination of FITC-, PE-, and APCconjugated secondary antibodies for anti-CD8, antiCD95, anti-CD28, anti-CD62L, anti-CD127, and antiCCR7 primary antibodies. Naïve and senescent CD8 cells were determined based on expression of $\mathrm{CD} 28$ and CD95 (Fas) [30]. CD62L, CD127, and CCR7 expression was measured in each group $\left(\mathrm{CD} 28^{+} \mathrm{CD} 95^{-} \mathrm{CD} 8^{+} \mathrm{T}\right.$ cells, $\mathrm{CD} 28^{+} \mathrm{CD} 95^{+} \mathrm{CD} 8^{+} \mathrm{T}$ cells, $\mathrm{CD} 28^{-} \mathrm{CD} 95^{+} \mathrm{CD} 8^{+} \mathrm{T}$ cells). Each experiment included cells incubated with isotype controls. A total of 100,000 events for each sample were recorded and analyzed on an LSRII flow cytometer (BD Biosciences). The analysis was performed using FlowJo Software (TreeStar, Ashland, CA). Forward-angle light scatter was used to exclude dead and aggregated cells [30].

\subsection{Determination of $\mathrm{T}$ Cell Proliferative Response}

PBMCs were resuspended in RPMI 1640 complete medium supplemented with $10 \%$ FCS, $50 \mathrm{mM}$ 2-ME, 25 $\mathrm{mM}$ HEPES-buffered saline, $2 \mathrm{mM}$ glutamine, $100 \mathrm{U} / \mathrm{ml}$ penicillin, and $100 \mathrm{mg} / \mathrm{ml}$ streptomycin and were stimulated with phytohaemagglutinin (PHA) at a concentration of $10 \mu \mathrm{g} / \mathrm{ml}$. Proliferation of PBMCs after PHA stimulation was determined using the $\left[{ }^{3} \mathrm{H}\right]$-thymidine incorporation method, as we previously described [33, 34]. Briefly, the PBMC cultures were pulsed with $\left[{ }^{3} \mathrm{H}\right]-$ thymidine (Amersham Pharmacia Biotech) $18 \mathrm{~h}$ before harvest. Proliferation was estimated by measuring the incorporation of $\left[{ }^{3} \mathrm{H}\right]$-thymidine into the cells on days 3 (D3 PHA) and 7 (D7 PHA) after stimulation and after addition of anti-Fas antibody at day 2 (D3 PHA+antiFas) and 4 (D7 PHA+anti-Fas) to induce apoptosis. We were unable to analyze some of the 34 subjects for the proliferation assay (6 subjects) and cytokine assay (8 subjects) due to low baseline cell counts or small sample volumes.

\subsection{Measurement of Lipid Profile}

These were carried out using the Ektachem DT II system as described by Hunter, et al. [35]. With this system, highdensity lipoprotein-cholesterol (HDL-C) is measured after precipitation of low-density lipoprotein (LDL) and very low-density lipoprotein (VLDL) with dextran sulfate and magnesium chloride. Control sera with low and high substrate concentrations were analyzed with each group of samples, and values for these controls were required to fall within accepted ranges before samples were analyzed. The DT II instrument was calibrated every 6 months with reagents supplied by the manufacturer. LDL was estimated using the Friedewald formula [36].

\subsection{Statistical Analysis}

The results are expressed as the mean and standard deviation (SD). The two-tailed Student's t-test and paired t-test were used for comparison between high- and low$25(\mathrm{OH}) \mathrm{D}$ groups. A partial correlation coefficient controlling for total body fat and/or age was calculated for the association between 25(OH)D levels and frequencies of naïve $\mathrm{CD} 8 \mathrm{~T}$ cells. A one-way analysis of variance (ANOVA) was used when more than two groups of samples were compared. Repeated measurements of ANOVA were used to compare proliferative responses and activation-induced cell death between $25(\mathrm{OH}) \mathrm{D}$ groups. Multiple linear regressions were used to determine whether age and/or total body fat had an effect on the association between 25(OH)D levels and frequencies of CD8 T cells. Raw data for cytokines were normalized by logarithmic transformation for statistical analysis. $\mathrm{P}<0.05$ was considered to be a statistically significant difference or correlation.

\section{RESULTS}

\section{1. $\mathrm{CD}^{2} 8^{+} \mathrm{CD} 95^{-} \mathrm{CD}^{+} \mathrm{T}$ Cells Express High Levels of CCR7, CD127, and CD62L}

As we demonstrated in our previous study [30], the pool of $\mathrm{CD} 28^{+} \mathrm{CD} 95^{-} \mathrm{CD} 8^{+} \mathrm{T}$ cells is mainly composed of naïve $\mathrm{CD} 8^{+} \mathrm{T}$ cells, which have high expression of CD45RA and CD127 and high numbers of TREC ${ }^{+}$cells. In this study, we analyzed the expression of CD62L, CD127, and CCR7, which are highly expressed in resting, naïve $\mathrm{T}$ cells [37]. We confirmed that the $\mathrm{CD} 28^{+} \mathrm{CD} 95^{-}$ subpopulation of $\mathrm{CD} 8 \mathrm{~T}$ cells expresses higher levels of CCR7, CD127 and CD62L compared with CD28 ${ }^{+} \mathrm{CD} 95^{+}$ and $\mathrm{CD} 28^{-} \mathrm{CD} 5^{+}$subpopulations of $\mathrm{CD}^{+} \mathrm{T}$ cells (Figure 1). Although there are overlaps among subpopulations of $\mathrm{CD}^{+} \mathrm{T}$ cells, we showed that differrential expression of $\mathrm{CD} 28$ and $\mathrm{CD} 95$ allows for the identification of naïve, memory, and senescent (terminally differentiated memory) $\mathrm{CD} 8^{+} \mathrm{T}$ cell subsets.

\section{2. $\mathrm{CD}^{2} 8^{+} \mathrm{CD} 95^{-} \mathrm{CD} 8^{+} \mathrm{T}$ Cell Frequencies Are Higher in the Low-25(OH)D ( $\leq 30 \mathrm{ng} / \mathrm{ml}$ ) Group}

Among the 34 subjects analyzed for this study, 19 par- 


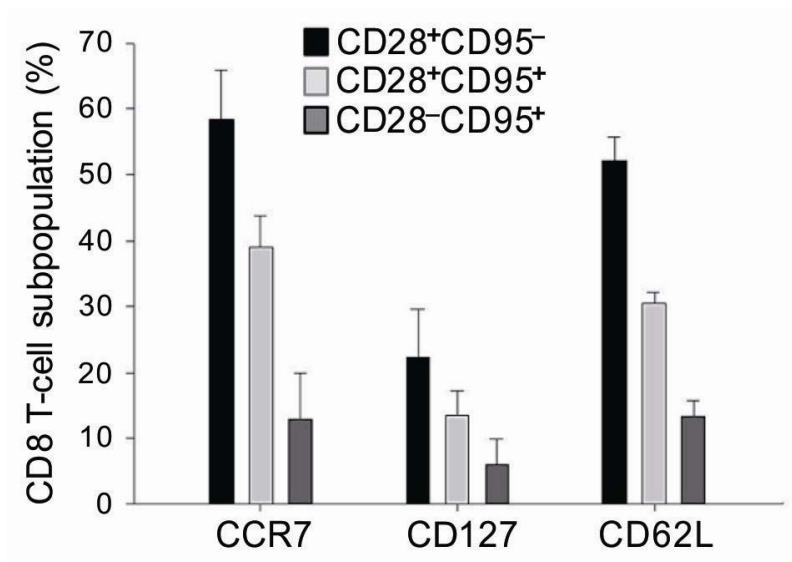

Figure 1. CCR7, CD127, and CD62L expression (\%) among CD8 T cell phenotypes (subjects $n=28$ ). Error bars represent the standard error of the mean (SEM).

ticipants $(56 \%)$ had hypovitaminosis $(\leq 30 \mathrm{ng} / \mathrm{ml}$, mean $23.7 \pm 4.8$ ), and 15 participants $(44 \%)$ had $>30 \mathrm{ng} / \mathrm{ml}$ (mean $42.2 \pm 10.3$ ) serum levels of vitamin D. There was no statistically significant difference in age, race, BMI, total body fat, lipid profile, or bone density between the two groups, although the low-25(OH)D group had a higher percentage of African-American (high-25(OH)D group, $6.2 \%$; low-25(OH)D group, $23.3 \%$ ) and a higher mean age (Table 1). However, 25(OH)D levels were inversely correlated with the frequency of naïve CD8 T cells (partial correlation coefficient, $-0.362, p=0.049$, controlled for total body fat; partial correlation coefficient, $-0.422, p=0.023$, controlled for total body fat and age, Figures 2(a) and (b)).

There was a statistically significant higher percentage of $\mathrm{CD} 28^{+} \mathrm{CD}^{-} 5^{-} \mathrm{CD}^{+}$(naïve) $\mathrm{T}$ cells $(13.3 \pm 11.5 \%, \mathrm{p}=$ 0.037 ) and lower percentage of $\mathrm{CD} 28^{+} \mathrm{CD} 95^{+} \mathrm{CD} 8^{+}$(effector) $\mathrm{T}$ cells $(36.2 \pm 12.1 \%, \mathrm{p}=0.004)$ in subjects with lower levels of 25(OH)D. By contrast, subjects with higher levels of $25(\mathrm{OH}) \mathrm{D}$ exhibited very low percentages of naïve CD8 $\mathrm{T}$ cells $(6.5 \pm 6.0 \%)$ but very high percentages of $\mathrm{CD} 28^{+} \mathrm{CD} 95^{+}$effector $\mathrm{CD} 8^{+} \mathrm{T}$ cells $(51.5 \pm$ $16.4 \%$, Figure 2(c)). Using a linear regression analysis, there was no statistical correlation between the frequentcies of effector CD8 $\mathrm{T}$ cells and levels of $25(\mathrm{OH}) \mathrm{D}(\mathrm{R}=$ $0.287, \mathrm{p}=0.099, \mathrm{n}=34)$. The percentage of naive $\mathrm{CD} 8^{+}$ $\mathrm{T}$ cells remained different between the two groups when adjusted for age and/or total body fat (\%). Although there were increased frequencies of $\mathrm{CD} 28^{-} \mathrm{CD} 95^{+} \mathrm{CD} 8^{+}$(senescent) $\mathrm{T}$ cells in the low-25(OH)D group (low-25[OH]D group, $38.0 \pm 19.5 \%$; high- $25(\mathrm{OH}) \mathrm{D}$ group, $26.2 \pm$ $12.0 \%, \mathrm{p}=0.44$ ), this difference between the two groups was not significant when adjusted for age and body fat ( $\mathrm{p}$ $=0.254$, Figure 2(c)). Furthermore, although there was no statistically significant difference in race between the two groups, there was an increased frequency of African-American women in the low-25(OH)D group (low-
25(OH)D group, 33.3\%; high-25(OH)D group, 6.2\%). When data sets only from Caucasian women $(\mathrm{n}=28)$ were analyzed, the results, though suggestive of similar trends, did not achieve a statistically significant difference in the frequency of naive $\mathrm{CD}^{+} \mathrm{T}$ cells (low$25(\mathrm{OH}) \mathrm{D}$ group, $12.6 \%$; high-25(OH)D group, $5.9 \%$, $\mathrm{p}=$ 0.073 ) and senescent $\mathrm{CD} 8^{+} \mathrm{T}$ cells (low-25(OH)D group, $35.2 \%$; high-25(OH)D group, $26.4 \%, \mathrm{p}=0.148)$ between the two groups $(\mathrm{n}=15$ and $\mathrm{n}=13$ for the high-25(OH)D group and low-25(OH)D group, respectively). However, the difference in effector $\mathrm{T}$ cells remained significant in Caucasian women (low-25(OH)D group, 38.8\%; high$25(\mathrm{OH}) \mathrm{D}$ group, $52.5 \%, \mathrm{p}=0.02$, Figure 2(d)).

\subsection{T Cell Proliferative Response and Anti-Fas Response Were Not Different between 25(OH)D Groups}

One of the major changes in human $\mathrm{T}$ cell functions associated with aging is diminished proliferation in response to antigenic stimulation [38]. Vitamin D can exert a potent growth-inhibitory, antiproliferative or pro-differentiating action on a wide variety of cell types through binding with the nuclear vitamin D receptor (VDR) [39].

Table 1. Demographic and clinical characteristic comparison between high- and low-25(OH)D groups.

\begin{tabular}{|c|c|c|c|c|}
\hline & 25(OH)D level & Mean & SD & $\begin{array}{c}\mathbf{p} \\
\text { value }\end{array}$ \\
\hline \multirow{2}{*}{ Age (year) } & $25(\mathrm{OH}) \mathrm{D}<30$ & 64.9 & 4.3 & 0.386 \\
\hline & $25(\mathrm{OH}) \mathrm{D} \geq 30$ & 63.8 & 3.2 & \\
\hline \multirow{2}{*}{ Race (Caucasian \%) } & $25(\mathrm{OH}) \mathrm{D}<30$ & 66.7 & & 0.090 \\
\hline & $25(\mathrm{OH}) \mathrm{D} \geq 30$ & 93.8 & & \\
\hline \multirow{2}{*}{$25(\mathrm{OH}) \mathrm{D}(\mathrm{ng} / \mathrm{ml})$} & $25(\mathrm{OH}) \mathrm{D}<30$ & 23.1 & 4.1 & \\
\hline & $25(\mathrm{OH}) \mathrm{D} \geq 30$ & 41.8 & 10.1 & \\
\hline \multirow{2}{*}{$\operatorname{BMI}\left(\mathrm{kg} / \mathrm{m}^{2}\right)$} & $25(\mathrm{OH}) \mathrm{D}<30$ & 27.6 & 2.9 & 0.769 \\
\hline & $25(\mathrm{OH}) \mathrm{D} \geq 30$ & 28.1 & 3.8 & \\
\hline \multirow{2}{*}{ Total body fat (\%) } & $25(\mathrm{OH}) \mathrm{D}<30$ & 43.8 & 6.5 & 0.903 \\
\hline & $25(\mathrm{OH}) \mathrm{D} \geq 30$ & 43.5 & 7.0 & \\
\hline \multirow{2}{*}{$\begin{array}{l}\text { Total body BMD } \\
\left(\mathrm{gm} / \mathrm{cm}^{2}\right)\end{array}$} & $25(\mathrm{OH}) \mathrm{D}<30$ & 1.2 & 0.1 & 0.606 \\
\hline & $25(\mathrm{OH}) \mathrm{D} \geq 30$ & 1.1 & 0.1 & \\
\hline \multirow{2}{*}{ Cholesterol (mg/dL) } & $25(\mathrm{OH}) \mathrm{D}<30$ & 203.7 & 52.0 & 0.86 \\
\hline & $25(\mathrm{OH}) \mathrm{D} \geq 30$ & 206.5 & 35.6 & \\
\hline \multirow{2}{*}{$\begin{array}{l}\text { Triglyceride } \\
(\mathrm{mg} / \mathrm{dL})\end{array}$} & $25(\mathrm{OH}) \mathrm{D}<30$ & 118.6 & 46.3 & 0.847 \\
\hline & $25(\mathrm{OH}) \mathrm{D} \geq 30$ & 115.7 & 39.6 & \\
\hline \multirow{2}{*}{ HDL (mg/dL) } & $25(\mathrm{OH}) \mathrm{D}<30$ & 53.1 & 14.3 & 0.057 \\
\hline & $25(\mathrm{OH}) \mathrm{D} \geq 30$ & 62.4 & 13.1 & \\
\hline \multirow{2}{*}{$\mathrm{LDL}(\mathrm{mg} / \mathrm{dL})$} & $25(\mathrm{OH}) \mathrm{D}<30$ & 126.9 & 43.6 & 0.650 \\
\hline & & 120.9 & 30.9 & \\
\hline
\end{tabular}



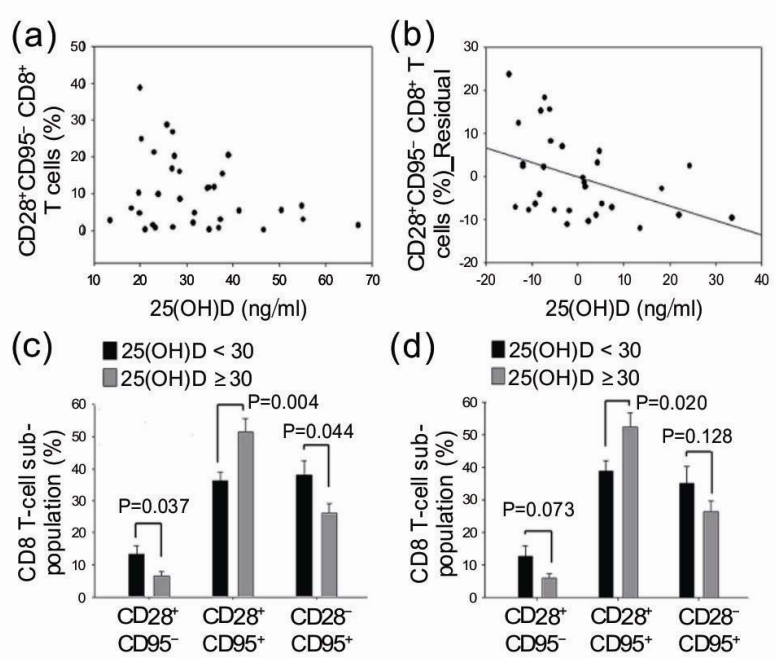

(d)

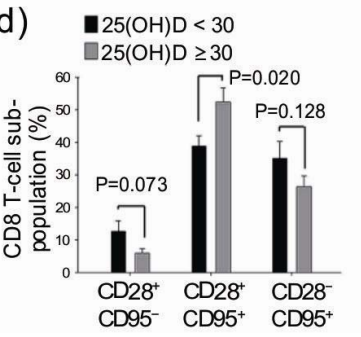

Figure 2. (a) The percentage of naïve and effector T cells was plotted against the 25(OH)D level of each individual. Each data point is the number obtained from a single individual. (b) The percentages of naïve $\mathrm{T}$ cells were negatively correlated with 25-hydroxy vitamin D $(25(\mathrm{OH}) \mathrm{D}$, partial correlation coefficient, $-0.362, p=0.049$, controlled for total body fat). (c) The low-25(OH)D $(<30 \mathrm{ng} / \mathrm{ml})$ group has a higher percentage of naïve and senescent $\mathrm{T}$ cells and a lower percentage of effector $\mathrm{T}$ cells. Mean values of naïve, effector, and senescent $\mathrm{T}$ cells for each group were plotted, and the error bar denotes the standard error of the mean (SEM). Total subjects $(n=34)$. (d) Comparison of $\mathrm{T}$ cell phenotypes (\%) between the two groups in Caucasian women $(\mathrm{n}=28)$.

Activated T lymphocytes from normal human subjects are known to express the specific high-affinity receptor for 1,25-dihydroxyvitamin D3 (1,25-(OH)2-D3) [40]. Therefore, we investigated the $\mathrm{T}$ cell proliferative response and anti-Fas antibody-mediated apoptosis. After PHA stimulation, the results did not show statistically significant differences in [3H]-thymidine incorporation at day 3 (D3 PHA) and day 7 (D7 PHA) between the two groups nor anti-Fas antibody-mediated suppression of the T cell proliferative response (Figure 3(a)). Given the disparity in sample size between races (Caucasian, $\mathrm{n}=$ 22; African-American, $\mathrm{n}=6$ ) for the proliferation assay, the statistical comparison was not ideal, although we observed marked racial differences in $\mathrm{T}$ cell proliferative response and anti-Fas antibody-induced cell death (Figure 3(b)).

\subsection{Various Cytokine Levels Were Not Different between 25(OH)D Groups}

Assessments of $\mathrm{T}$ cell responses in elderly humans that indicate changes in cytokine profiles and an imbalance in the production of various cytokines, such as IL-2 and IFN- $\gamma$, may reflect a dysregulation that results in a decreased proliferative response in lymphocytes with increasing age [41]. In addition, differentiation and main tenance of CD8 $\mathrm{T}$ cells are influenced by the cytokine milieu $[42,43]$. Vitamin D is an important regulator of the immune system, and effector $\mathrm{T}$ cell cytokine production is also regulated by vitamin $\mathrm{D}$, which stimulates transforming growth factor (TGF) and interleukin 4 (IL-4) production [44] and reduces the production and/or expression of the Th1-associated cytokines, such as TNF- $\alpha$ and IFN- $\gamma$, in T cells [45-47]. Therefore, we measured and compared cytokine levels according to $\mathrm{T}$ cell phenoltypes and serum 25(OH)D levels. However, there were no significant associations between various cytokine levels and CD8 T cell phenotypes. In addition, cytokine levels were not statistically different between the two $25(\mathrm{OH}) \mathrm{D}$ groups, although the high-25(OH)D group exhibited higher levels of IL-4, IL-6, and IL-17 as well as lower levels of IL-1 (Figure 4(a)). Caucasian women had consistently higher levels of cytokines than African-American women, but statistical comparison was limited due to the discrepancy in sample size (Figure 4 (b)).

\section{DISCUSSION}

This is the first study showing that higher $25(\mathrm{OH}) \mathrm{D}$ levels are associated with decreased frequencies of naïve $\mathrm{T}$ cells and increased frequencies of effector $\mathrm{T}$ cells in the young elderly. The wide distribution of the percen-
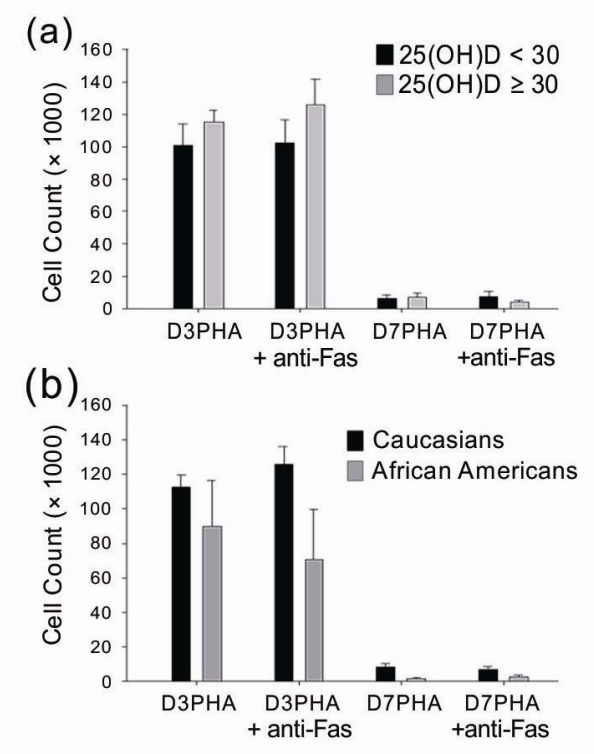

Figure 3. T cell proliferative response and anti-Fas antibod$y$-mediated suppression of $\mathrm{T}$ cell proliferation. (a) There was no difference in T cell activation and activation-induced cell death between the two groups. (b) African-American subjects tend to have lower cell number, proliferative response, and anti-Fas $\mathrm{Ab}$-mediated cell death, but there were no significant differences between races (Caucasian, $\mathrm{n}=22$; African American, $\mathrm{n}=$ $6)$. Error bars denote the standard error of the mean (SEM). 

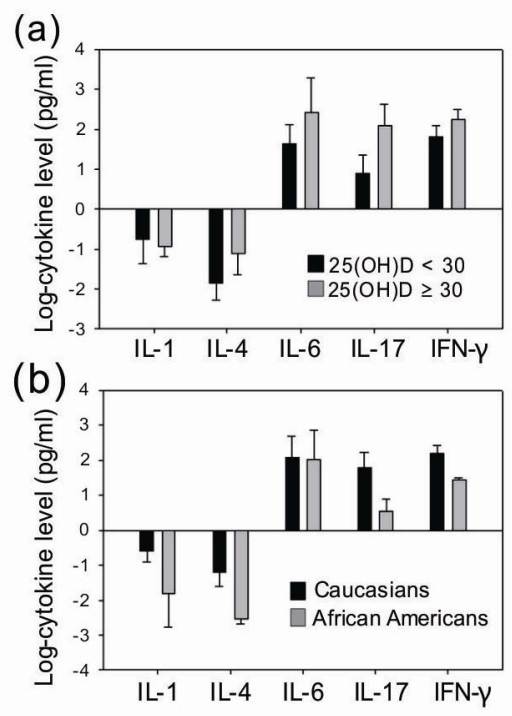

Figure 4. Cytokine level (log-transformed) comparison (a) between 25(OH)D groups and (b) between races (Caucasian, $\mathrm{n}=$ 21; African-American, $n=5$ ). Error bar denotes standard error of the mean (SEM).

tages of naïve CD8 T cells with 25(OH)D levels less than $30 \mathrm{ng} / \mathrm{ml}$ suggests that lower 25(OH)D levels do not affect naïve CD8 $\mathrm{T}$ cells. This was expected, because naïve $\mathrm{T}$ cells do not express VDR. By contrast, the high$25(\mathrm{OH}) \mathrm{D}$ group had a $47 \%$ lower frequency of naïve CD8 T cells compared with the low-25(OH)D group, and the frequency of naïve $T$ cells was uniformly low in the high-25(OH)D group. This may imply that the underlying mechanisms of maintaining high vitamin $\mathrm{D}$ accelerates central thymic involution, thus decreasing naïve $\mathrm{T}$ cell production. Although lympho-hematopoietic defect or dysfunction caused by high vitamin D is very unlikely, this possibility cannot be excluded, because hematologic data were not gathered in this study. Our findings are consistent with the novel concept that phosphate and vitamin $\mathrm{D}$ metabolism participate in the regulation of aging $[21,22,24]$. The Klotho gene encodes a novel type I membrane protein of the beta-glycosidase family, functioning as an aging-suppressor gene that extends life span when overexpressed. The Klotho gene mutation in mouse results in a syndrome that resembles accelerated human aging, including a short lifespan, vascular calcifications, soft-tissue calcifications, skin atrophy, osteoporosis, and premature thymic involution as well as hypoglycemia, hyperphosphatemia, and, paradoxically, high plasma calcitriol levels [23]. However, a vitamin D-deficient diet rescued premature aging phenotypes in Klotho knockout mice [22, 24]. Hypervitaminosis D accompanied by klotho deficiency may mediate these thymic epithelial defects and also affect thymic differentiation of dendritic cells [48,49]. These in vivo studies together with our findings suggest that vitamin $\mathrm{D}$ has a role in immunologic aging processes. Increased frequencies of effector $\mathrm{T}$ cells in the high25(OH)D group are likely due to augmented $\mathrm{T}$ cell signaling and $\mathrm{T}$ cell activation via VDR expression on $\mathrm{T}$ cells. Information about vitamin D supplementation was not available in this study, and it is not clear whether higher 25(OH)D levels and decreased frequencies of naïve $\mathrm{T}$ cells were caused by genetic differences, such as the Klotho mutation or VDR polymorphism, or by differences in environmental exposure or vitamin $\mathrm{D}$ supplementation. In addition, the $25(\mathrm{OH}) \mathrm{D}$ level in the study participants ranged from 13.4 to $66.9 \mathrm{ng} / \mathrm{ml}(31.8 \pm 12.1)$, and the mean value of the high-25(OH)D group was only $41.77 \mathrm{ng} / \mathrm{ml}$, which is considered to be within the upper range of normal values. Data is limited in the range of very-low and very-high $25(\mathrm{OH}) \mathrm{D}$, and further research is needed to determine the range of deficient and toxic levels. Given the small number of participants, the naïve $\mathrm{T}$ cell percentages were not significantly different when analyzed only for Ca- ucasian women $(n=28, p=0.073)$ but the high-25(OH)D group of Caucasian women had a $47 \%$ lower frequency of naïve $\mathrm{T}$ cells than the low$25(\mathrm{OH}) \mathrm{D}$ group. However, African-American women had lower 25(OH)D levels $(\mathrm{n}=6,24.4 \pm 8.2)$ with a relatively higher naïve $\mathrm{T}$ cell percentage $(15.1 \pm 11.3 \%)$. A higher naïve $\mathrm{T}$ cell percentage in the low-vitamin $\mathrm{D}$ group could be confounded by this racial difference. $T$ cell differentiation and senescence are also regulated by neuroendorine and metabolic factors, such as GH/IGF-1, components of the mammalian target of rapamycin (mTOR) signaling pathway, and adipokines, but these were not directly measured in this study. Given the small sample size, significant individual variation, uneven racial distribution, and the narrow range of vitamin $\mathrm{D}$ levels in this study, we were not able to find any significant group differences in cytokine profile or proliferation/apoptosis. Analysis of the proliferative responses of subpopulations of CD8 T cells would be beneficial to determine if naïve or effector CD8 T cells from lowor high-25(OH)D group exhibit differential proliferative responses, and if modulations of the levels of $25(\mathrm{OH}) \mathrm{D}$ can affect the response. Such studies will help to identify the functional effects of vitamin $\mathrm{D}$ on specific populations of CD8 T cells from older subjects.

Decreased frequencies of naïve CD8 T cells and increased frequencies of effector CD8 T cells are consistently observed with aging, and this pattern is more prominent with chronic CMV antigenemia in the elderly [50] and is associated with increased mortality in nonagenarians [51]. In addition, a decreased immunologic repertoire may pose increased risk of serious infection and decreased vaccination response [52]. We observed that the high-25(OH)D group exhibited typical immunologic changes of aging in this study. There are no studies on the direct association between these immu- 
nologic changes and adverse health outcomes, including all-cause mortality. Thus, it remains unclear whether these findings imply adverse effects from higher 25$(\mathrm{OH}) \mathrm{D}$ levels in young elderly women. Given the current practice of vitamin D supplementation and the lack of data on extra-skeletal health, further studies on the immunologic effects of vitamin D and their related health outcomes are urgently needed.

\section{ACKNOWLEDGEMENTS}

The project was supported by the National Institute of Health grants R01AG027084-01, P30-DK56336, T32DK062710-07, as well as the sponsorship of the Deep South Resource Center for Minority Aging Research (1P30AG031054-01, provided by the National Institute on Aging). We thank Dr. Paul Todd for critical review of the manuscript. Flow cytometry was carried out at the UAB Comprehensive Flow Cytometry Core (P30 AR048311 and P30 AI027767).

\section{REFERENCES}

[1] Gruver, A.L., Hudson, L.L. and Sempowski, G.D. (2007) Immunosenescence of ageing. Journal of Pathology, 211, 144-156. doi:10.1002/path.2104

[2] Hadrup, S.R., Strindhall, J., Kollgaard, T., Seremet, T., Johansson, B., et al. (2006) Longitudinal studies of clonally expanded CD8 $\mathrm{T}$ cells reveal a repertoire shrinkage predicting mortality and an increased number of dysfunctional cytomegalovirus-specific T cells in the very elderly. Journal of Immunology, 176, 2645-2653.

[3] Weng, N.P., Akbar, A.N. and Goronzy, J. (2009) CD28(-) $T$ cells: Their role in the age-associated decline of immune function. Trends in Immunology, 30, 306-312. doi:10.1016/j.it.2009.03.013

[4] Weng, N.P. (2008) Telomere and adaptive immunity. Mechanisms of Ageing and Development, 129, 60-66. doi:10.1016/j.mad.2007.11.005

[5] Wilkins, C.H., Sheline, Y.I., Roe, C.M., Birge, S.J. and Morris, J.C. (2006) Vitamin D deficiency is associated with low mood and worse cognitive performance in older adults. The American Journal of Geriatric Psychiatry, 14, 1032-1040. doi:10.1097/01.JGP.0000240986.74642.7c

[6] Holick, M.F. (2004) Vitamin D: Importance in the prevention of cancers, type 1 diabetes, heart disease, and osteoporosis. The American Journal of Clinical Nutrition, 79, 362-371.

[7] Holick, M.F. (2006) High prevalence of vitamin D inadequacy and implications for health. Mayo Clinic Proceedings, 81, 353-373. doi:10.4065/81.3.353

[8] Buell, J.S., Scott, T.M., Dawson-Hughes, B., Dallal, G.E., Rosenberg, I.H., et al. (2009) Vitamin D is associated with cognitive function in elders receiving home health services. Journal of Gerontology. Series A: Biological Sciences and Medical Sciences, 64, 888-895. doi:10.1093/gerona/glp032

[9] Wei, M.Y., Garland, C.F., Gorham, E.D., Mohr, S.B. and Giovannucci, E. (2008) Vitamin D and prevention of co- lorectal adenoma: A meta-analysis. Cancer Epidemiology Biomarkers and Prevention, 17, 2958-2969. doi:10.1158/1055-9965.EPI-08-0402

[10] Drechsler, C., Pilz, S., Obermayer-Pietsch, B., Verduijn, M., Tomaschitz, A., et al. (2010) Vitamin D deficiency is associated with sudden cardiac death, combined cardiovascular events, and mortality in haemodialysis patients. European Heart Journal, 31, 2253-2261. doi: 10.1093/eurheartj/ehq246

[11] Grandi, N.C., Breitling, L.P. and Brenner, H. (2010) Vitamin D and cardiovascular disease: Systematic review and meta-analysis of prospective studies. Preventive $\mathrm{Me}$ dicine, 51, 228-233. doi: 10.1016/j.ypmed.2010.06.013

[12] Pittas, A.G., Lau, J., Hu, F.B. and Dawson-Hughes, B. (2007) The role of vitamin D and calcium in type 2 diabetes. A systematic review and meta-analysis. Journal of Clinical Endocrinology and Metabolism, 92, 2017-2029. doi: $10.1210 /$ jc. $2007-0298$

[13] Dobnig, H., Pilz, S., Scharnagl, H., Renner, W., Seelhorst, U., et al. (2008) Independent association of low serum 25-hydroxyvitamin $\mathrm{d}$ and 1,25-dihydroxyvitamin d levels with all-cause and cardiovascular mortality. Archives of Internal Medicine, 168, 1340-1349. doi:10.1001/archinte.168.12.1340

[14] Bischoff-Ferrari, H.A., Giovannucci, E., Willett, W.C., Dietrich, T. and Dawson-Hughes, B. (2006) Estimation of optimal serum concentrations of 25-hydroxyvitamin D for multiple health outcomes. The American Journal of Clinical Nutrition, 84, 18-28.

[15] Heaney, R.P. (2009) Optimal vitamin D status. Journal of Bone and Mineral Research, 24, 755. doi:10.1359/jbmr.081219

[16] Holick, M.F. (2007) Vitamin D deficiency. The New England Journal of Medicine, 357, 266-281. doi:10.1056/NEJMra070553

[17] Michaelsson, K., Baron, J.A., Snellman, G., Gedeborg, R., Byberg, L., et al. (2010) Plasma vitamin D and mortality in older men: A community-based prospective cohort study. The American Journal of Clinical Nutrition, 92, 841-848. doi:10.3945/ajen.2010.29749

[18] Melamed, M.L., Michos, E.D., Post, W. and Astor, B. (2008) 25-hydroxyvitamin D levels and the risk of mortality in the general population. Archives of Internal Medicine, 168, 1629-1637.

doi:10.1001/archinte.168.15.1629

[19] Steingrimsdottir, L., Gunnarsson, O., Indridason, O.S., Franzson, L. and Sigurdsson, G. (2005) Relationship between serum parathyroid hormone levels, vitamin D sufficiency, and calcium intake. The Journal of the American Medical Association, 294, 2336-2341. doi:10.1001/jama.294.18.2336

[20] Sanders, K.M., Stuart, A.L., Williamson, E.J., Simpson, J.A., Kotowicz, M.A., et al. (2010) Annual high-dose oral vitamin $\mathrm{D}$ and falls and fractures in older women: A randomized controlled trial. The Journal of the American Medical Association, 303, 1815-1822. doi:10.1001/jama.2010.594

[21] Ohnishi, M., Nakatani, T., Lanske, B., Razzaque, M.S. (2009) Reversal of mineral ion homeostasis and soft- tissue calcification of Klotho knockout mice by deletion of 
vitamin D 1alpha-hydroxylase. Kidney International, 75, 1166-1172. doi:10.1038/ki.2009.24

[22] Forster, R.E., Jurutka, P.W., Hsieh, J.C., Haussler, C.A., Lowmiller, C.L., et al. (2011) Vitamin D receptor controls expression of the anti-aging klotho gene in mouse and human renal cells. Biochemical and Biophysical Research Communications, 414, 557-562. doi:10.1016/j.bbrc.2011.09.117

[23] Kato, S., Takeyama, K., Kitanaka, S., Murayama, A., Sekine, K., et al. (1999) In vivo function of VDR in gene expression-VDR knock-out mice. The Journal of Steroid Biochemistry and Molecular Biology, 69, 247-251. doi:10.1016/S0960-0760(99)00042-4

[24] Kamei, Y., Kawada, T., Fukuwatari, T., Ono, T., Kato, S., et al. (1995) Cloning and sequencing of the gene encoding the mouse vitamin D receptor. Gene, 152, 281-282. doi:10.1016/0378-1119(94)00735-B

[25] Veldman, C.M., Cantorna, M.T. and DeLuca, H.F. (2000) Expression of 1,25-dihydroxyvitamin $\mathrm{D}_{3}$ receptor in the immune system. Archives of Biochemistry and Biophysics, 374, 334-338. doi:10.1006/abbi.1999.1605

[26] Von Essen, M.R., Kongsbak, M., Schjerling, P., Olgaard, K., Odum, N., et al. (2010) Vitamin D controls T cell antigen receptor signaling and activation of human $\mathrm{T}$ cells. Nature Immunology, 11, 344-349. doi:10.1038/ni.1851

[27] Meehan, T.F. and DeLuca, H.F. (2002) The vitamin D receptor is necessary for 1alpha,25-dihydroxyvitamin $\mathrm{D}_{3}$ to suppress experimental autoimmune encephalomyelitis in mice. Archives of Biochemistry and Biophysics, 408, 200-204. doi:10.1016/S0003-9861(02)00580-5

[28] Ross, A.C., Manson, J.E., Abrams, S.A., Aloia, J.F., Brannon, P.M. et al. (2011) The 2011 report on dietary reference intakes for calcium and vitamin D from the Institute of Medicine: What clinicians need to know. The Journal of Clinical Endocrinology and Metabolism, 96, 53-58. doi:10.1210/jc.2010-2704

[29] Tuohimaa, P., Tenkanen, L., Ahonen, M., Lumme, S., Jellum, E. et al. (2004) Both high and low levels of blood vitamin $\mathrm{D}$ are associated with a higher prostate cancer risk: A longitudinal, nested case-control study in the Nordic countries. International Journal of Cancer, 108, 104108. doi:10.1002/ijc. 11375

[30] Chen, J., Li, J., Lim, F.C., Wu, Q., Douek, D.C., et al. (2010) Maintenance of naive CD8 T cells in nonagenarians by leptin, IGFBP3 and T3. Mechanisms of Ageing and Development, 131, 29-37. doi:10.1016/j.mad.2009.11.003

[31] Rutella, S., Rumi, C., Lucia, M.B., Etuk, B., Cauda, R., et al. (1998) Flow cytometric detection of perforin in normal human lymphocyte subpopulations defined by expression of activation/differentiation antigens. Immunology Letters, 60, 51-55. doi:10.1016/S0165-2478(97)00132-6

[32] Kaech, S.M., Tan, J.T., Wherry, E.J., Konieczny, B.T., Surh, C.D., et al. (2003) Selective expression of the interleukin 7 receptor identifies effector CD8 T cells that give rise to long-lived memory cells. Nature Immunology, 4, 1191-1198. doi:10.1038/ni1009

[33] Hsu, H.C., Shi, J., Yang, P., Xu, X., Dodd, C. et al. (2001) Activated $\mathrm{CD} 8(+) \mathrm{T}$ cells from aged mice exhibit de- creased activation-induced cell death. Mechanisms of Ageing and Development, 122, 1663-1684. doi:10.1016/S0047-6374(01)00279-2

[34] Hsu, H.C., Scott, D.K., Zhang, P., Zhou, J., Yang, P., et al. (2006) CD8 T-cell immune phenotype of successful aging. Mechanisms of Ageing and Development, 127, 231-239. doi:10.1016/j.mad.2005.10.001

[35] Hunter, G.R., Chandler-Laney, P.C., Brock, D.W., LaraCastro, C., Fernandez, J.R., et al. (2009) Fat Distribution, Aerobic Fitness, Blood Lipids, and Insulin Sensitivity in African-American and European-American Women.

[36] Friedewald, W.T., Levy, R.I. and Fredrickson, D.S. (1972) Estimation of the concentration of low-density lipoprotein cholesterol in plasma, without use of the preparative ultracentrifuge. Clinical Chemistry, 18, 499-502.

[37] Appay, V., van Lier, R.A., Sallusto, F., Roederer, M. (2008) Phenotype and function of human T lymphocyte subsets: Consensus and issues. Cytometry Part A: The Journal of the International Society for Analytical Cytology, 73, 975-983. doi:10.1002/cyto.a.20643

[38] Murasko, D.M., Weiner, P. and Kaye D. (1987) Decline in mitogen induced proliferation of lymphocytes with increasing age. Clinical and Experimenal Immunology, 70, 440-448.

[39] Eelen, G., Gysemans, C., Verlinden, L., Vanoirbeek, E., De Clercq, P., et al. (2007) Mechanism and potential of the growth-inhibitory actions of vitamin D and analogs. Current Medicinal Chemistry, 14, 1893-1910. doi:10.2174/092986707781058823

[40] Lemire, J.M., Adams, J.S., Sakai, R. and Jordan, S.C. (1984) 1 alpha,25-dihydroxyvitamin $\mathrm{D}_{3}$ suppresses proliferation and immunoglobulin production by normal human peripheral blood mononuclear cells. The Journal of Clinical Investigation, 74, 657-661. doi:10.1172/JCI111465

[41] Goonewardene, I.M. and Murasko, D.M. (1993) Age associated changes in mitogen induced proliferation and cytokine production by lymphocytes of the long-lived brown Norway rat. Mechanisms of Ageing and Development, 71, 199-212. doi:10.1016/0047-6374(93)90084-5

[42] Badovinac, V.P., Messingham, K.A., Jabbari, A., Haring, J.S. and Harty, J.T. (2005) Accelerated CD8+ T-cell memory and prime-boost response after dendritic-cell vaccination. Nature Medicine, 11, 748-756. doi: $10.1038 / \mathrm{nm} 1257$

[43] Haring, J.S., Badovinac, V.P. and Harty J.T. (2006) Inflaming the CD8+ T cell response. Immunity, 25, 19-29. doi:10.1016/j.immuni.2006.07.001

[44] Cantorna, M.T., Woodward, W.D., Hayes, C.E. and DeLuca, H.F. (1998) 1,25-dihydroxyvitamin $\mathrm{D}_{3}$ is a positive regulator for the two anti-encephalitogenic cytokines TGF-beta 1 and IL-4. Journal of Immunology, 160, 53145319.

[45] Rigby, W.F., Denome, S. and Fanger, M.W. (1987) Regulation of lymphokine production and human T lymphocyte activation by 1,25 -dihydroxyvitamin $\mathrm{D}_{3}$. Specific inhibition at the level of messenger RNA. The Journal of Clinical Investigation, 79, 1659-1664. doi:10.1172/JCI113004

[46] Lemire, J.M. (1992) Immunomodulatory role of 1,25- 
dihydroxyvitamin $\mathrm{D}_{3}$. Journal of Cellular Biochemistry, 49, 26-31. doi:10.1002/jcb.240490106

[47] Tang, J., Zhou, R., Luger, D., Zhu, W., Silver, P.B., et al. (2009) Calcitriol suppresses antiretinal autoimmunity through inhibitory effects on the Th17 effector response. Journal of Immunology, 182, 4624-4632. doi:10.4049/jimmunol.0801543

[48] Ferreira, G.B., van Etten, E., Lage, K., Hansen, D.A., Moreau, Y., et al. (2009) Proteome analysis demonstrates profound alterations in human dendritic cell nature by TX527, an analogue of vitamin D. Proteomics, 9, 37523764. doi:10.1002/pmic. 200800848

[49] Min, D., Panoskaltsis-Mortari, A., Kuro, O.M., Hollander, G.A., Blazar, B.R., et al. (2007) Sustained thymopoiesis and improvement in functional immunity induced by exogenous KGF administration in murine models of aging. Blood, 109, 2529-2537.

doi:10.1182/blood-2006-08-043794
[50] Wikby, A., Johansson, B., Olsson, J., Lofgren, S., Nilsson, B.O., et al. (2002) Expansions of peripheral blood CD8 T-lymphocyte subpopulations and an association with cytomegalovirus seropositivity in the elderly: The Swedish NONA immune study. Experimental Gerontology, 37, 445-453. doi:10.1016/S0531-5565(01)00212-1

[51] Wikby, A., Ferguson, F., Forsey, R., Thompson, J., Strindhall, J. et al. (2005) An immune risk phenotype, cognitive impairment, and survival in very late life: Impact of allostatic load in Swedish octogenarian and nonagenarian humans. Journal of Gerontology. Series A: Biological Sciences and Medical Sciences, 60, 556-565. doi:10.1093/gerona/60.5.556

[52] Grubeck-Loebenstein, B., Della, B.S., Iorio, A.M., Michel, J.P., Pawelec, G., et al. (2009) Immunosenescence and vaccine failure in the elderly. Aging Clinical and Experimental Research, 21, 201-209. 